\title{
Potential Probiotic Enterococcus faecium OV3-6 and Its Bioactive Peptide as Alternative Bio-Preservation
}

\author{
Thiwanya Choeisoongnern ${ }^{1,2}{ }^{\circ}$, Sasithorn Sirilun ${ }^{1, *}$, Rungaroon Waditee-Sirisattha ${ }^{3}{ }^{\oplus}$, Komsak Pintha ${ }^{4}$, \\ Sartjin Peerajan ${ }^{5}$ and Chaiyavat Chaiyasut ${ }^{2, *}$ (i) \\ 1 Department of Pharmaceutical Sciences, Faculty of Pharmacy, Chiang Mai University, \\ Chiang Mai 50200, Thailand; thiwanya_c@cmu.ac.th \\ 2 Innovation Center for Holistic Health, Nutraceuticals, and Cosmeceuticals, Faculty of Pharmacy, \\ Chiang Mai University, Chiang Mai 50200, Thailand \\ 3 Department of Microbiology, Faculty of Science, Chulalongkorn University, Bangkok 10330, Thailand; \\ rungaroon.w@chula.ac.th \\ 4 Division of Biochemistry, School of Medical Sciences, University of Phayao, Phayao 56000, Thailand; \\ komsakjo@gmail.com \\ 5 Health Innovation Institute, Chiang Mai 50200, Thailand; s.peerajan@gmail.com \\ * Correspondence: sasithorn.s@cmu.ac.th (S.S.); chaiyavat@gmail.com (C.C.); \\ Tel.: +66-5394-4375 (S.S.); +66-5394-4340 (C.C.)
}

Citation: Choeisoongnern, T.; Sirilun, S.; Waditee-Sirisattha, R.; Pintha, K.; Peerajan, S.; Chaiyasut, C. Potential Probiotic Enterococcus faecium OV3-6 and Its Bioactive Peptide as Alternative Bio-Preservation. Foods 2021, 10, 2264. https://doi.org/ $10.3390 /$ foods 10102264

Academic Editor: Pascal Degraeve

Received: 26 July 2021

Accepted: 18 September 2021

Published: 24 September 2021

Publisher's Note: MDPI stays neutral with regard to jurisdictional claims in published maps and institutional affiliations.

Copyright: (c) 2021 by the authors. Licensee MDPI, Basel, Switzerland. This article is an open access article distributed under the terms and conditions of the Creative Commons Attribution (CC BY) license (https:// creativecommons.org/licenses/by/ $4.0 /)$.

\begin{abstract}
Probiotic Enterococcus faecium OV3-6 and its secreted active peptide were characterized and investigated. The strain survived in simulated gastric and small intestinal conditions at $88.16 \%$ and $94.33 \%$, respectively. The safety assessment revealed that the strain was shown $\alpha$-hemolysis and susceptible to most clinically relevant antibiotics, but intermediate sensitivity to erythromycin and kanamycin was found. It does not harbor any virulence genes except for the $e f a A_{f m}$ gene. Both of its living cells and the cell-free supernatants (CFS) of the strain significantly reduced the adhesion of E. coli and S. Typhi on Caco-2 cells. The strain can regulate the secretion of pro and inflammatory cytokines, IL- 6 and IL-12 and induce the secretion of anti-inflammatory IL-10 of the Caco-2 cell. The strain can prevent the growth of Gram-positive strains belonging to the genera Bacillus, Carnobacterium, Listeria, and Staphylococcus. It also presented the entP gene that involves the production of bacteriocin named enterocin $\mathrm{P}$. The antimicrobial peptide was matched $40 \%$ with $50 S$ ribosomal proteins L29 (7.325 kDa), as revealed by LC-MS/MS. This active peptide exhibits heat stability, is stable over a wide $\mathrm{pH}$ range of $2-10$, and maintains its activity at -20 and $4{ }^{\circ} \mathrm{C}$ for 12 weeks of storage. Altogether, E. faecium OV3-6 thus has potential for consideration as a probiotic and bio-preservative for applied use as a fermented food starter culture and in functional food or feed industries.
\end{abstract}

Keywords: probiotics; Enterococci; cell adhesion; immunomodulatory; antimicrobial peptides; bacteriocin; ribosomal proteins; bio-preservation

\section{Introduction}

The contamination of undesirable microorganisms in foods is the initial problem that leads to serious foodborne illness cases in humans and the loss of product in food industrials. Particularly, local fermented foods have been highly contaminated by undesirable microorganisms and toxins [1]. The government regulations and consumer demands push the food manufacturers to find the natural preservatives to control the contaminating microbes primarily responsible for food spoilage and poisoning.

Lactic acid bacteria (LAB) are Gram-positive cocci or bacilli, aerotolerant, homofermentative or heterofermentative, and lactic acid producers [2]. LAB has been used in starter culture that plays a vital role in fermentation as flavorings and texturizing or preservative agents [3]. Interestingly, the metabolites of LAB exert antimicrobial activity. Because of 
generally regarded as safe (GRAS) status, the use of LAB or their metabolites as a natural preservative in food has gained much importance [3]. Several LABs have played a role as potential probiotics as live microorganisms, which, when administered in adequate amounts, confer a health benefit on the host [4]. Most human probiotic belongs to of Lactobacillus spp. and Bifidobacterium spp. [5], whereas less information exists about the effectiveness of enterococcal strains as probiotics. Enterococci belong to the LAB group, which is widespread in foods and the environment, and they inhabit the gastrointestinal (GI) tract of mammals and other animals [6]. It has been recognized as the leading cause of hospital-acquired infections [7]. To date, the genus Enterococcus has not yet obtained the status GRAS. However, Enterococcus strains are currently recognized as probiotic and commercially available [8]. Potential probiotics have been reported to modulate gut microbiota, inhibit pathogens adhesion, increase gastrointestinal barrier function, induce anti-inflammatory cytokine and suppress pro-inflammatory cytokines [9], and to have cholesterol-lowering activity [10]. However, enterococci are associated with vancomycin resistance and nosocomial infections. Therefore, to ensure the safety and use of enterococci in foods or as probiotics there must be enough data based on case-by-case studies.

Enterococci usually produce many substances with antimicrobial activity, including antimicrobial peptides (AMPs) known as bacteriocins. Bacteriocins are small, ribosomal synthesized, extracellularly released bacterial peptide or protein molecules that can kill some closely-related bacteria [11]. However, nisin from Lactococcus lactis is one commercially produced bacteriocin widely used as a food additive [12]. These AMPs represent an alternative to antibiotic treatment and can also inhibit foodborne pathogens by forming pores in the membrane of target cells, which are the main mechanisms of its action [13].

Besides bacteriocin, ribosomal proteins (RPs) also have an antimicrobial activity [14]. RPs are components of the small and large subunit of ribosomes, which act like the machinery for protein synthesis in prokaryotic and eukaryotic cells. L27 and L30 proteins are a component of the 50S ribosomal subunit secreted from the Lactobacillus salivarius SGL 03 strain that can function as AMPs [15]. However, the survey of antimicrobial activity of RPs remains incomplete, and information as such is extremely limited [14].

The present study aimed to investigate and characterize the antimicrobial activity, adhesion properties, immunomodulatory and secreted AMPs, and potential active peptide secreted from probiotic E. faecium OV3-6 for its future intended use in the food/feed industry.

\section{Materials and Methods}

\subsection{Microbial Strains Cultivation}

The probiotic strain of E. faecium OV3-6 (GenBank accession number: MN453594) was isolated from fermented plant (Houttuynia cordata Thunb.) beverages, and the key probiotic properties were evaluated and collected in Chiang Mai, Thailand [16]. The strain was propagated in de Man Rogosa and Sharpe (MRS) medium at $37^{\circ} \mathrm{C}$. Antimicrobial tested strains included Listeria ivanovii SLCC 2379 were obtained from Institute National de la Recherche Agronomique (INRA), Nantes, France. Brochothrix thermosphacta DSMZ 20171 ${ }^{\mathrm{T}}$, Carnobacterium maltaromaticum NCDO 2760, Staphylococcus aureus CIP 76.25, Escherichia coli CIP 76.24, and Listeria innocua CIP $80.11^{\mathrm{T}}$ were obtained from Ecole Nationale Nantes Atlantique Vétérinaire, Agroalimentaire et de l'Alimentation (ONIRIS), Nantes, France. Bacillus cereus ATCC 11778, Clostridium perfringens, Cronobacter sakazakii ATCC BAA-894, Escherichia coli ATCC 5922, Propionibacterium acnes ATCC 6919, Pseudomonas aeruginosa ATCC 27853, Salmonella Typhi DMST 22842, Salmonella Typhimurium TISTR 1469, Shigella sonnei, S. aureus ATCC 5923, Staphylococcus epidermidis ATCC 12228, Streptococcus mutans ATCC 25175, Vibrio harveyi ATCC BAA-1119 and Candida albicans ATCC 90028 were obtained from the culture collection of Faculty of Pharmacy, Chiang Mai University (CMU), Thailand. The tested strains were cultured in Brain Heart Infusion (BHI) medium at $37^{\circ} \mathrm{C}$, except $B$. thermosphacta was grown at $25^{\circ} \mathrm{C}$, and yeast was cultured in Sabouraud Dextrose Broth (SDB). In PCR amplification of virulence and bacteriocin genes, Enterococcus spp. from CMU, Enterococcus faecalis CM6CR07 and E. faecalis CF1GI14, which kindly 
provided by Hwanhlem [17], were grown in MRS medium and used as a positive control. All microorganism culture mediums used in this study were punched from Himedia (Mumbai, India).

\subsection{Probiotic Properties and Safety Assessment}

\subsubsection{Survival in Simulated Gastric Juice and Small Intestinal Condition}

The culture of E. faecium OV3-6 $(18 \mathrm{~h})$ was harvested by centrifugation $\left(4{ }^{\circ} \mathrm{C}\right.$ at $10,000 \times g$ for $5 \mathrm{~min}$ ). The cell pellet was resuspended in simulated gastric juice containing $3 \mathrm{~g} / \mathrm{L}$ pepsin (Sigma-Aldrich, St. Louis, MO, USA) in phosphate-buffered saline (PBS) $\mathrm{pH} 2.5$ and incubated at $37^{\circ} \mathrm{C}$ for $0,1,2,3$, and $4 \mathrm{~h}$. Aliquots of $0.1 \mathrm{~mL}$ were taken and then bacteria were washed with PBS pH 7.0 to determine the total viable count on MRS agar. After incubating at $37^{\circ} \mathrm{C}$ for $24 \mathrm{~h}$, the survival cell was enumerated. The percentage survival of the bacteria was calculated as Equation (1) [18], where N1 is the number of initially inoculated viable cells $(\mathrm{CFU} / \mathrm{mL})$, and $\mathrm{N} 2$ is the number of survived viable cells $(\mathrm{CFU} / \mathrm{mL})$.

$$
\% \text { survival }=(\log N 2 / \log N 1) \times 100
$$

For the small intestinal condition tolerance, the cell pellet was resuspended in PBS solution containing $0.3 \%(w / v)$ bile salts (Sigma-Aldrich) and $1 \mathrm{mg} / \mathrm{mL}$ pancreatin (SigmaAldrich), $\mathrm{pH}$ 8.0. The bile salt resistant cell was assessed after incubation at $37^{\circ} \mathrm{C}$ for $0,1,2$, 4 , and $6 \mathrm{~h}$. Aliquots of $0.1 \mathrm{~mL}$ were taken and then bacteria were washed and neutralized with PBS pH 7.0. The total viable cells was enumerated on MRS agar after incubation at $37^{\circ} \mathrm{C}$ for $24 \mathrm{~h}$. The percentage survival of the bacteria was calculated as Equation (1) [18].

\subsubsection{Bile Salt Hydrolase (BSH) Activity}

The bacteria culture $(16 \mathrm{~h})$ was streaked on MRS agar, which was supplemented with $0.5 \%(w / v)$ sodium salt of taurodeoxycholic acid (TDCA) (Sigma-Aldrich) and $0.37 \mathrm{~g} / \mathrm{L}$ of calcium chloride (UNILAB, Sydney, NSW, Australia). Plates were incubated at $37^{\circ} \mathrm{C}$ for $72 \mathrm{~h}$. The presence of precipitated bile acid surrounding colonies (halo zone) indicated the positive bile salt hydrolase activity of bacteria [19].

\subsubsection{Hemolytic Activity}

The bacteria culture (16 h) of E. faecium OV3-6 was streaked on sheep blood agar. The plate was incubated at $37^{\circ} \mathrm{C}$ for $48 \mathrm{~h}$. After incubation, the hemolytic reaction was observed in appearance zones around colonies. The absence of zones and greenish zones was interpreted as $\gamma$-hemolysis and $\alpha$-hemolysis (negative hemolytic activity). When presented, the clearing zone around colonies was considered as $\beta$-hemolysis (positive hemolytic activity) [20].

\subsubsection{Determination of Antibiotic Susceptibility}

Antibiotic susceptibility of E. faecium OV3-6 was determined by the disk diffusion method [18,21]. Briefly, the test bacteria were grown in a broth culture medium for $18 \mathrm{~h}$ before the test, and the bacteria cell was resuspended in PBS (0.5 McFarland equivalent to $10^{8} \mathrm{CFU} / \mathrm{mL}$ ). Bacteria suspension was swabbed on Mueller-Hinton agar (MHA) (Himedia). The antibiotic disks consisting of $10 \mu \mathrm{g}$ ampicillin, $30 \mu \mathrm{g}$ chloramphenicol, $2 \mu \mathrm{g}$ clindamycin, $15 \mu \mathrm{g}$ erythromycin, $10 \mu \mathrm{g}$ gentamicin, $30 \mu \mathrm{g}$ kanamycin, 10 Unit penicillin $\mathrm{G}$, $25 \mu \mathrm{g}$ streptomycin, $30 \mu \mathrm{g}$ tetracycline, and $30 \mu \mathrm{g}$ vancomycin were placed on the agar plate by aseptic technique. All the antibiotics disks in this study were purchased from Himedia. After incubation at $37^{\circ} \mathrm{C}$ for $24 \mathrm{~h}$, the growth inhibition zone diameters $(\mathrm{mm})$ around the disk were measured. The results were interpreted according to the breakpoints recommended by The Clinical and Laboratory Standards Institute (CLSI, 2016) guidelines. With the exception of kanamycin, gentamicin, streptomycin, and clindamycin were interpreted according to breakpoints proposed by Nueno-Palop [21]. 


\subsubsection{Evaluation of Virulence-Associated Genes}

The presence of virulence-associated genes was evaluated by polymerase chain reaction (PCR). The genomic DNA of E. faecium OV3-6 was extracted by using the NucleoSpin ${ }^{\circledR}$ Microbial DNA kit (Macherey-Nagel, Düren, Germany). The primer and amplification conditions were performed following in Table S1. The target genes were ace (adhesin of collagen protein), asa1 (aggregation substance), cylA, cylB (cytolysins), $e f a A_{f s}$ (cell wall adhesion in E. faecalis), efa $A_{f m}$ (cell wall adhesion in E. faecium), esp (enterococcal surface protein), hyl (encodes the hyaluronidase), and gelE (encodes the protease GelE with gelatinase activity) $[11,22,23]$. The PCR mixtures were performed in $25 \mu \mathrm{L}$ final volume containing $50 \mathrm{ng}$ of DNA template, $0.25 \mu \mathrm{M}$ of each primer, $2.5 \mu \mathrm{L}$ of $10 \times$ PCR buffer containing $35 \mathrm{mM} \mathrm{MgCl} 2,1 \mathrm{U}$ of Taq DNA polymerase, $2.5 \mu \mathrm{L}$ of dNTPs mixture (2.5 mM each). All PCR reactions were purchased from iNtRON (iNtRON Biotechnology, Inc., Gyeonggi, South Korea). Amplifications were carried out by using DW-T960 Smart Gradient PCR Thermal Cycler (Drawell, Shanghai, China) with the condition of initial denature at $94{ }^{\circ} \mathrm{C}$ for $5 \mathrm{~min}$, followed by 35 cycles of denaturation at $94{ }^{\circ} \mathrm{C}$ for $1 \mathrm{~min}$, annealing at an appropriate temperature for $1 \mathrm{~min}$, extension at $72{ }^{\circ} \mathrm{C}$ for $1 \mathrm{~min}$ and a final extension step of 5 min at $72{ }^{\circ} \mathrm{C}$. The DNA from strains E. faecalis EFA70 and EFA14 were used as a positive control. Amplification products were separated on a 1.5\% agarose gel containing RedSafe ${ }^{\mathrm{TM}}$ nucleic acid staining solution (iNtRON) in $1 \times$ TAE buffer for $35 \mathrm{~min}$ at $100 \mathrm{~V}$. And made visible by UV trans-illumination.

\subsection{Inhibition of Adhesion on Caco-2 Cell Model}

\subsubsection{Cell Culture}

The Caco-2 cell line (No. RCB0988) (RIKEN BioResource Research Center, Ibaraki, Japan) were cultured in Dulbecco's Modified Eagle's Medium (DMEM) (Gibco, NY, USA) containing 10\% $(v / v)$ fetal bovine serum (FBS) (Gibco), $2 \mathrm{mM} \mathrm{L-glutamine} \mathrm{(Gibco),} \mathrm{and} \mathrm{1 \%}$ $(v / v)$ antibiotic solution ( $100 \mathrm{U} / \mathrm{mL}$ penicillin and $100 \mu \mathrm{g} / \mathrm{mL}$ streptomycin) (Gibco). The cell was incubated at $37^{\circ} \mathrm{C}$ under a $5 \% \mathrm{CO}_{2}$ atmosphere and $95 \%$ relative humidity. For bacteria binding to Caco-2 cells and inhibition of adhesion assays, the cell was placed in 24-well plates to obtain semiconfluent monolayers for $72 \mathrm{~h}$ [24]. The culture was replaced with antibiotic-free and FBS-free fresh DMEM for $24 \mathrm{~h}$ before the assay was performed and used at $\geq 80 \%$ confluence to avoid association with the well [25].

\subsubsection{Inhibition of Enteropathogenic Bacterial Adhesion}

The binding of enteropathogenic E. coli, S. Typhi, and E. faecium OV3-6 to Caco-2 intestinal epithelial cells was studied using a previously modified method [26]. Briefly, Caco-2 cells were treated with $0.2 \mathrm{~mL}$ overnight in culture bacteria $\left(10^{7} \mathrm{CFU} / \mathrm{mL}\right)$ in a cell medium without antibiotic and $\mathrm{FBS}$ at $37{ }^{\circ} \mathrm{C}$ under a $5 \% \mathrm{CO}_{2}$ atmosphere and $95 \%$ relative humidity for $1 \mathrm{~h}$. The Caco-2 cells were washed with PBS to remove unbound bacteria. Adherent bacteria were harvested by using $0.5 \%$ Triton X-100 solution (Sigma-Aldrich) and centrifuged at $10,000 \times g$ for $5 \mathrm{~min}$. Viable bacterial cells associated with Caco-2 cells were plated on an MRS agar medium. After incubation at $37^{\circ} \mathrm{C}$ for $24 \mathrm{~h}$, colony counts were performed. The binding rate was expressed as a percentage using Equation (2) [27], where $\mathrm{A} 1$ is the number of initial bacterial cells $(\mathrm{CFU} / \mathrm{mL})$ added to the well and $\mathrm{A} 2$ is the number of adherent bacterial cells $(\mathrm{CFU} / \mathrm{mL})$.

$$
\% \text { adherence }=(\log \mathrm{A} 2 / \log \mathrm{A} 1) \times 100
$$

The inhibition of E. coli and S. Typhi adhesion by E. faecium OV3-6 were performed using a modified method [24]. The bacterial cell and CFS of E. faecium OV3-6 were prepared. E. faecium OV3-6 was cultured in an MRS broth medium at $37^{\circ} \mathrm{C}$ for $18 \mathrm{~h}$ and centrifuged at $10,000 \times g$ for $5 \mathrm{~min}$ to separate the bacterial cell and the supernatant. $200 \mu \mathrm{L}$ of CFS or $10^{7} \mathrm{CFU} / \mathrm{mL}$ of E. faecium OV3-6 were inoculated at $37^{\circ} \mathrm{C}$ with pathogenic bacteria $\left(10^{7} \mathrm{CFU} / \mathrm{mL}\right)$ as co-incubation or $1 \mathrm{~h}$ pre-incubated before pathogenic bacteria or $1 \mathrm{~h}$ 
post-incubated after pathogen. After incubation, adherent bacteria were harvested with $0.5 \%$ Triton $X-100$ solution, centrifuged at $10,000 \times g$ for $5 \mathrm{~min}$ and cultured on selective media for $24 \mathrm{~h}$ at $37^{\circ} \mathrm{C}$. The percentage inhibition of pathogen adhesion was expressed using the following Equation (3) [24], where T1 is the number of adherent pathogenic bacteria cells (CFU/mL) in the presence of probiotic and $\mathrm{T} 2$ is the number of adherent pathogenic bacteria cells $(\mathrm{CFU} / \mathrm{mL})$ in the absence of probiotic.

$$
\text { Inhibition of adhesion }(\%)=(1-(\mathrm{T} 1 / \mathrm{T} 2)) \times 100
$$

\subsection{Immunomodulation Associated with Inflammatory Cytokines}

The cytokine assay was modified to that carried out in previous studies [28]. Briefly, monolayer Caco-2 cells were co-cultured with $1 \mathrm{ng} / \mathrm{mL}$ of lipopolysaccharide (LPS), E. faecium OV3-6, enteropathogenic E. coli, S. Typhi, and S. Typhimurium (10 $\left.{ }^{7} \mathrm{CFU} / \mathrm{mL}\right)$. After incubation at $37{ }^{\circ} \mathrm{C}$ in a $5 \% \mathrm{CO}_{2}$ and $95 \%$ air atmosphere for $24 \mathrm{~h}$, the CFS was collected by centrifugation. The cytokines IL-6, IL-12, and IL-10 concentration in the CFS were evaluated by enzyme-linked immunosorbent assay (ELISA) using a commercially available immunoassay kit (Quantikine by R\&D Systems, Minneapolis, MN, USA). Caco-2 cells without treatment are used as a negative control.

\subsection{Antimicrobial Activity against Pathogenic Bacteria}

The antimicrobial activity of E. faecium OV3-6 was performed by agar well diffusion assay as modified method from previous studies [28]. E. faecium OV3-6 was grown in MRS broth at $37{ }^{\circ} \mathrm{C}$ for $18 \mathrm{~h}$. The CFS was obtained by centrifugation at $4{ }^{\circ} \mathrm{C}$ at $10,000 \times g$ for $5 \mathrm{~min}$. A $40 \mu \mathrm{L}$ of CFS was added to the well (5 mm diameter) into $20 \mathrm{~mL}$ appropriate soft agar medium ( $1 \%$ agar) containing a final concentration $10^{6} \mathrm{CFU} / \mathrm{mL}$ of the tested strain. After incubation at the optimal growth condition of tested strains, the clear zones size around the wells containing CFS was observed.

The CFS was neutralized, treated with $1 \mathrm{mg} / \mathrm{mL}$ catalase (Sigma-Aldrich) and $1 \mathrm{mg} / \mathrm{mL}$ proteinase K (Sigma-Aldrich) for $1 \mathrm{~h}$ at $37^{\circ} \mathrm{C}$ to eliminate the effect of acidic, hydrogen peroxide, and active protein, respectively. The antimicrobial activity against $S$. aureus CIP 76.25 as a sensitive tested strain of treated CFS was tested by agar well diffusion assay. The antimicrobial activity was expressed in arbitrary units per milliliter (AU/mL). An arbitrary unit (AU) was defined as $40 \mu \mathrm{L}$ of the highest dilution of the twofold serial dilution, which showed a minimal visible inhibition zone against the sensitive cells of tested strain following in Equation (4) [29], where D is the dilution factor, and V is the volume of CFS $(\mu \mathrm{L})$.

$$
\mathrm{AU} / \mathrm{mL}=(1000 / \mathrm{V}) \times \mathrm{D}
$$

\subsection{Confirmation of Bacteriocin-Encoding Gene}

The detection of bacteriocin-encoding genes in E. faecium OV3-6 was evaluated by polymerase chain reaction (PCR). The primer and amplification condition using in this study was described in Table S1. The target genes were genus Enterococcus, ent $A$, ent $B$, entP, entL50A, entL50B, ent31, entQ, and entAS48 [11,30]. The obtained DNA template and PCR condition were described above (Section 2.2.5).

\subsection{Partial Purification of AMPs}

E. faecium OV3-6 was cultured in $1000 \mathrm{~mL}$ of the MRS broth medium at $37^{\circ} \mathrm{C}$ for $24 \mathrm{~h}$. The cells were removed by centrifugation $\left(10,000 \times g, 4{ }^{\circ} \mathrm{C}\right.$ for $\left.10 \mathrm{~min}\right)$. The supernatant was filtered through the filter $(0.22 \mu \mathrm{m}$ pore size $)$ and assayed for AMPs activity against $S$. aureus CIP 76.25 as tested strain by agar well diffusion assay following in Equation (3) [29].

The supernatant was purified by gently adding ammonium sulfate (RCI-Labscan, Bangkok, Thailand) to obtain $70 \%$ saturation and stirred overnight (maintained at $4{ }^{\circ} \mathrm{C}$ ). The saturated supernatant was centrifuged at $12,000 \times g, 4{ }^{\circ} \mathrm{C}$ for $30 \mathrm{~min}$. The pellet was resuspended in $20 \mathrm{mM}$ potassium phosphate buffer $\left(20 \mathrm{mM} \mathrm{K}_{2} \mathrm{HPO}_{4}, 20 \mathrm{mM} \mathrm{KH} \mathrm{PO}_{4}\right.$, pH7) [31] before being assayed for AMP activity by an agar well diffusion assay as de- 
scribed above. The crude proteinaceous solution was further fractionated by size using Amicon ${ }^{\circledR}$ Ultra centrifugal filter devices (Merck Millipore, Darmstadt, Germany) with a different molecular weight cut-off (MWCO) which is 50,000, 30,000, and 10,000 MWCO. The AMPs activity and protein concentration were performed in each step of purification. The final AMPs fraction was maintained at $-20{ }^{\circ} \mathrm{C}$ and subsequently used for further characterization [32].

\subsection{Molecular Mass and Amino Acid Sequence Determination of AMPs}

The molecular weight determination of AMPs was performed using sodium dodecyl sulfate-polyacrylamide gel electrophoresis (SDS-PAGE) according to the method described by Laemmli [33]. Briefly, the partially purified AMPs were resolved in SDS-PAGE with $12 \%(v / v)$ separating gel on the Mini-PROTEAN Tetra Cell (Bio-Rad, CA, USA). A $20 \mu \mathrm{L}$ of partially purified AMPs sample $(2.45 \mathrm{mg}$ protein $/ \mathrm{mL})$ was mixed with $20 \mu \mathrm{L} 2 \times$ sample buffer $(12.5 \%, v / v$ of $0.5 \mathrm{M}$ Tris- $\mathrm{HCl} \mathrm{pH} 6.8,25 \%, v / v$ of $25 \%$ glycerol, $20 \%, v / v$ of $10 \%$ SDS, $36.5 \%, v / v$ distilled water, $1 \%, v / v$ of $1 \%$ bromophenol blue, $5 \%, v / v \beta$-mercaptoethanol). A $10 \mu \mathrm{L}$ of the mixed sample was loaded into the gel. A low molecular weight protein marker (MW 1700 to 42,000 Da) (Cell-Signaling Technology, Beverly, MA, USA) was used to compare the protein's molecular weight. After electrophoresis, the gels were stained with coomassie blue G-250 stain solution for $2 \mathrm{~h}$ and destained until the stain background disappeared. The gels were washed in water for $1.5 \mathrm{~h}$ to remove the stain solution from the gels and sliced into 4 pieces [22]. One of the gels was overlaid with $20 \mathrm{~mL} \mathrm{BHI} \mathrm{soft}$ agar containing S. aureus CIP $76.25\left(10^{6} \mathrm{CFU} / \mathrm{mL}\right)$. The inhibition zone was observed after incubation at $37^{\circ} \mathrm{C}$ for $24 \mathrm{~h}$. The other gels were used for further determination of molecular mass and amino acid sequence.

The AMPs bands from SDS- PAGE gel were trypsin digested and peptides extracted according to standard techniques [34]. Peptides were analyzed by using liquid chromatographmass spectrometry/mass spectrometry (LC-MS/MS) instrument with electrospray ionization mass spectrometer of the Shimadzu Prominence nano HPLC system (Shimadzu, Tokyo, Japan) coupled to a 5600 TripleTOF mass spectrometer (AB SCIEX, Concord, ON, Canada). Tryptic peptides were loaded onto an Agilent Zorbax 300SB-C18, $3.5 \mu \mathrm{m}$ (Agilent Technologies, DE, Waldbronn, Germany) and separated with a linear gradient of water/acetonitrile/ $0.1 \%$ formic acid $(v / v)$. Spectra were analyzed to identify interest proteins using Mascot sequence matching software (Matrix Science, London, UK) with the MSPnr100 database.

\subsection{Enzyme Sensitivity, Physicochemical Treatments and Long-Term Storage of AMPs}

The effect of enzymes on partially purified AMPs was determined by incubating the AMPs with catalase, $\alpha$-chymotrypsin, trypsin, proteinase K (Sigma-Aldrich) with $1 \mathrm{mg} / \mathrm{mL}$ of final enzyme concentration for $1 \mathrm{~h}$ incubation at $37^{\circ} \mathrm{C}$ and then the reactions were stopped by boiling for $3 \mathrm{~min}$ [35]. Thermal sensitivity evaluation of partially purified AMPs was performed by keeping partially purified AMPs at $0,4,37,45,60$, and $100{ }^{\circ} \mathrm{C}$ for $0,15,30,60,90$, and $120 \mathrm{~min}$, and autoclaved at $121^{\circ} \mathrm{C}$ for $15 \mathrm{~min}$ [31]. The partially purified AMPs were adjusted from $\mathrm{pH} 2.0$ to 12.0 with $1 \mathrm{~N} \mathrm{HCl}$ or $1 \mathrm{~N} \mathrm{NaOH}$ to determine the effect of $\mathrm{pH}$ on partially purified AMPs. After $1 \mathrm{~h}$ of incubation at room temperature, the $\mathrm{pH}$ of samples was neutralized [36]. The effect of $\mathrm{NaCl}$ on partially purified AMPs was assayed by adding 10 and $30 \% \mathrm{NaCl}$ to the samples. The treated samples were stored at $4{ }^{\circ} \mathrm{C}$ for 1 month. Every week, the samples were taken to determine antimicrobial activity [22]. The partially purified AMPs were stored at $-20,4,37^{\circ} \mathrm{C}$ and room temperature for 3 months in long-term storage. The samples were collected to determine the antimicrobial activity [22]. A $1 \mathrm{mg} / \mathrm{mL}$ nisin as a commercial preservative was used as a positive control. The antimicrobial activity against $S$. aureus CIP 76.25 of each treated partially purified AMPs and nisin was assayed using the agar well diffusion assay. 


\subsection{Statistical Analysis}

All experiments were performed at least three replicates, and values are presented as mean \pm standard deviations. Data were conducted using SPSS software version 17.0 (SPSS Inc., Chicago, IL, USA). Significant differences between means were statistically tested using for one-way analysis of variance (ANOVA) with Duncan's post hoc test. Differences were considered significant at $p<0.05$.

\section{Results}

\subsection{Probiotic Properties and Safety Assessment}

E. faecium OV3-6 tolerated to simulated gastric juice (Figure S1a). The bacteria viability was unaffected in gastric juice $(p<0.05)$ during $1 \mathrm{~h}$ with survival abilities of $98.48 \%$. While at 2,3 , and $4 \mathrm{~h}$ of incubation, the percentage survival of the bacteria was decreased to 90.29 , 88.45 , and $88.16 \%$, respectively. Moreover, the strain OV3-6 showed resistance to simulated small intestine conditions with percentage survival of the strain during 1 and $2 \mathrm{~h}$ were $99.60,99.49$, respectively. However, their viability slightly decreased at 4 and $6 \mathrm{~h}$ exposure was 96.89 and $94.33 \%$, respectively (Figure S1b).

E. faecium OV3-6 showed the BSH activity with precipitation zone surrounding colonies. As safety claim, the strain showed blood $\alpha$-hemolysis or absence of hemolysis (data not shown). In the antibiotic susceptibility tests, the OV3-6 was sensitive to eight antibiotics, including ampicillin, chloramphenicol, clindamycin, gentamicin, penicillin $\mathrm{G}$, streptomycin, tetracycline, and vancomycin. However, the strain showed intermediate sensitivity to erythromycin and kanamycin.

The safety of E. faecium OV3-6 was investigated by the screening of genes encoding different virulent factors. PCR performed the presence of virulence genes encoding ace, asa1, cylA, cylB, efaAfs, esp, hyl, and gelE. The agarose gel electrophoresis revealed that $E$. faecium OV3-6 does not harbor any of these virulence genes except efa $A_{f m}$, which showed $735 \mathrm{bp}$ of amplification product (Figure 1).

(a)

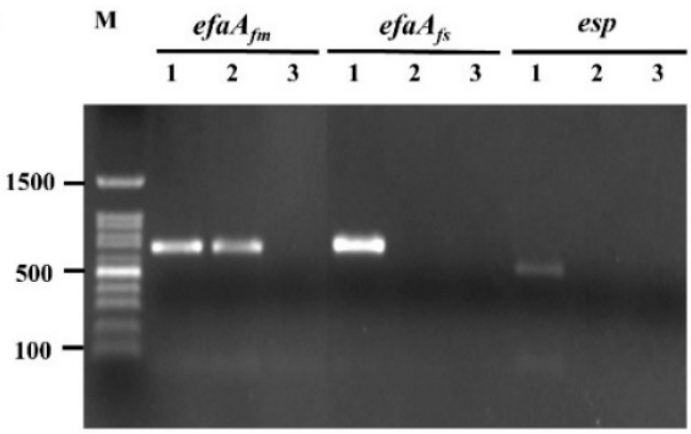

(c)

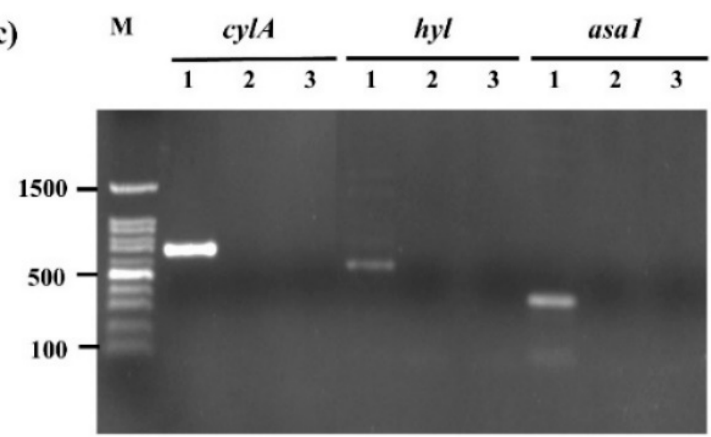

(b)

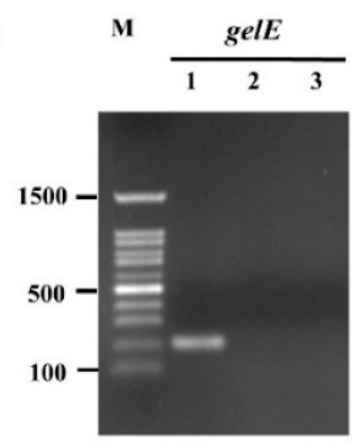

(d)

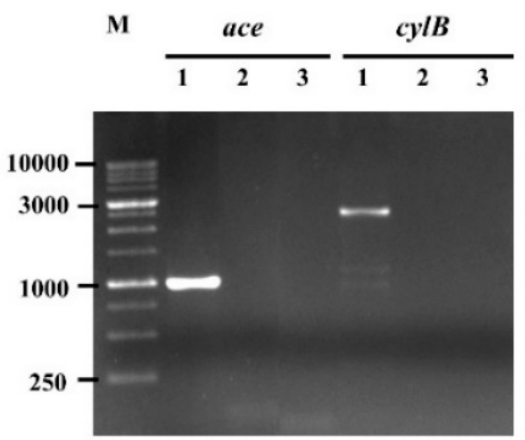

Figure 1. Amplification of virulence gene in E. faecium OV3-6 by PCR. (a) $e f a A_{f m}, e f a A_{f s}$, and esp genes; (b) gelE gene; (c) cylA, hyl, and asa1 genes; (d) ace and cylB genes; Lane M: 100 bp and 1 Kb DNA markers; Lanes 1: products of positive controls; Lanes 2: products of E. faecium OV3-6; Lanes 3: products of negative controls. 


\subsection{Inhibition of Adhesion on Caco-2 Cell Model}

The adhesion rate of E. faecium OV3-6, E. coli, and S. Typhi to Caco-2 cells were 89.76, 69.12 , and $92.15 \%$, respectively. All bacteria are a significant difference in adhesion rate.

In pre-incubation, the inhibition of $E$. coli adhesion to Caco-2 cells by living cell and CFS of E. faecium OV3-6 showed a significant decrease of 92.92 and $77.37 \%$, respectively. The co-incubation showed 76.25 and $42.08 \%$, respectively. And the post-incubation showed 34.17 and $18.33 \%$, respectively (Figure $2 \mathrm{a}$ ).

(a)

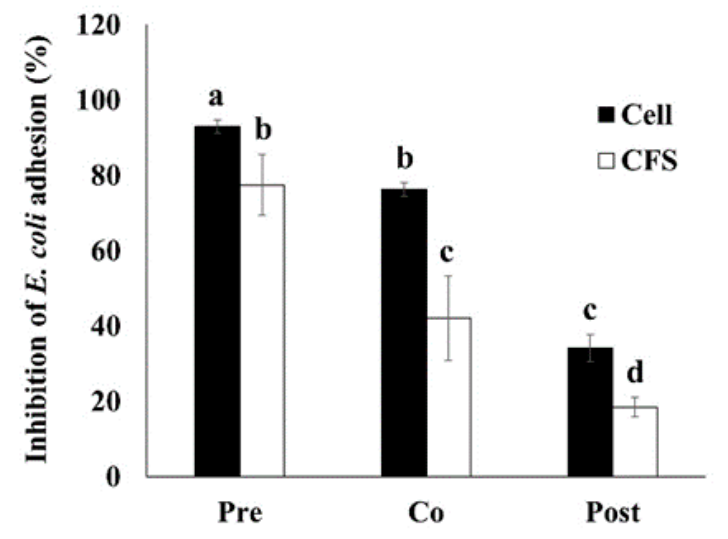

(b)

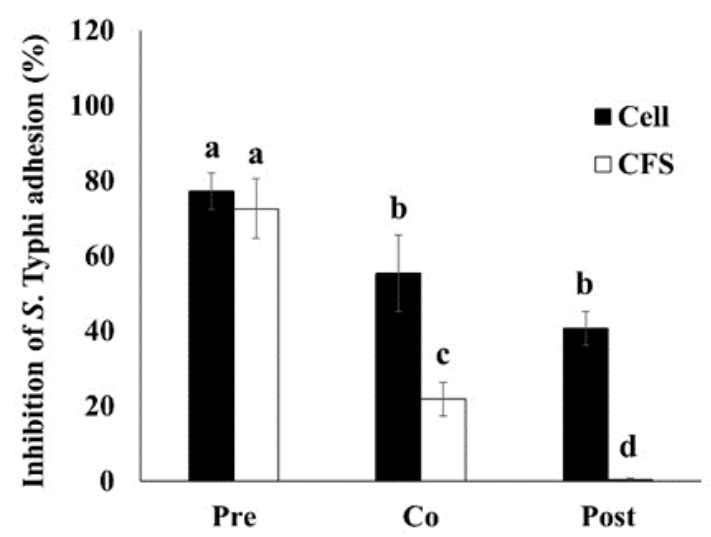

Figure 2. The inhibition of E. coli (a) and S. Typhi (b) adhesion to Caco-2 cell by bacteria cell and CFS of E. faecium OV3-6. Three conditions: E. faecium OV3-6 was treated on Caco-2 cell at $1 \mathrm{~h}$ before pathogenic bacteria was added as pre-incubation (Pre); E. faecium OV3-6 and pathogenic bacteria were added at the same time as co-incubation (Co); E. faecium OV3-6 was treated on Caco-2 cell at $1 \mathrm{~h}$ after pathogenic bacteria was added as post-incubation (Post). Data are shown as means \pm SD of triplicate experiments. The different letters above columns indicate that the values are significantly different $(p<0.05)$.

In pre-incubation, the inhibition of $S$. Typhi adhesion to Caco-2 cells by living cells and CFS of E. faecium OV3-6 showed 77.19 and $72.50 \%$, respectively (Figure $2 b$ ). The co-incubation showed a significant decrease with 55.31 and $21.87 \%$, respectively. And the post-incubation showed 40.62 and $0.31 \%$, respectively.

\subsection{Immunomodulation Associated with Inflammatory Cytokines}

The LPS significantly $(p<0.05)$ induced pro-inflammatory cytokine IL-6 secretion $(45.30 \pm 2.54 \mathrm{pg} / \mathrm{mL})$ higher than any treatments (Table 1). The E. faecium OV3-6 significantly induced IL-6 secretion $(12.36 \pm 2.80 \mathrm{pg} / \mathrm{mL})$ less than any treatments except untreated. S. Typhi, LPS, and E. coli significantly induced pro-inflammatory cytokine IL-12 secretion of $6.38 \pm 2.06,6.04 \pm 0.52$, and $5.59 \pm 1.38 \mathrm{pg} / \mathrm{mL}$, respectively. The E. faecium OV3-6 and the co-culture E. faecium OV3-6 with each pathogen or LPS significantly induced IL- 6 and IL-12 secretion less than only LPS and each pathogen. Each treatment increased anti-inflammatory cytokine IL-10 secretion when compared with untreated. $E$. faecium OV3-6 significantly induced IL-10 secretion $(247.59 \pm 17.43 \mathrm{pg} / \mathrm{mL})$ higher than any treatments. 
Table 1. Secretion of cytokines by Caco-2 when treated with LPS, E. coli, S. Typhi, S. Typhimurium, and E. faecium OV3-6.

\begin{tabular}{cccc}
\hline \multirow{2}{*}{ Treatments } & \multicolumn{3}{c}{ Secretion of Cytokines (pg/mL) } \\
\cline { 2 - 4 } & IL-6 & IL-12 & IL-10 \\
\hline Untreated & $5.67 \pm 0.41^{\mathrm{f}}$ & $0.34 \pm 0.03^{\mathrm{e}}$ & $8.32 \pm 1.33^{\mathrm{f}}$ \\
LPS & $45.30 \pm 2.54^{\mathrm{a}}$ & $6.04 \pm 0.52^{\mathrm{a}}$ & $99.84 \pm 4.05^{\mathrm{e}}$ \\
E. coli & $39.27 \pm 4.00^{\mathrm{b}}$ & $5.59 \pm 1.38^{\mathrm{a}}$ & $112.20 \pm 1.20^{\mathrm{d}, \mathrm{e}}$ \\
S. Typhi & $39.92 \pm 3.56^{\mathrm{b}}$ & $6.38 \pm 1.06^{\mathrm{a}}$ & $97.20 \pm 2.80^{\mathrm{e}}$ \\
S. Typhimurium & $37.00 \pm 0.61^{\mathrm{b}}$ & $4.03 \pm 1.00^{\mathrm{b}}$ & $126.18 \pm 15.10^{\mathrm{c}, \mathrm{d}}$ \\
E. faecium OV3-6 & $12.36 \pm 2.80^{\mathrm{e}}$ & $1.80 \pm 0.31^{\mathrm{d}}$ & $247.59 \pm 17.43^{\mathrm{a}}$ \\
LPS + E. faecium OV3-6 & $31.74 \pm 2.29^{\mathrm{c}}$ & $3.57 \pm 0.30^{\mathrm{b}, \mathrm{c}}$ & $110.02 \pm 2.24^{\mathrm{d}, \mathrm{e}}$ \\
E. coli + E. faecium OV3-6 & $26.58 \pm 5.48^{\mathrm{c}, \mathrm{d}}$ & $2.45 \pm 0.87^{\mathrm{c}, \mathrm{d}}$ & $130.57 \pm 10.30^{\mathrm{c}}$ \\
S. Typhi + E. faecium OV3-6 & $25.42 \pm 2.86^{\mathrm{d}}$ & $2.71 \pm 0.37^{\mathrm{b}, \mathrm{c}, \mathrm{d}}$ & $137.44 \pm 2.80^{\mathrm{c}}$ \\
S. Typhimurium + E. faecium OV3-6 & $22.80 \pm 2.73^{\mathrm{d}}$ & $1.97 \pm 0.42^{\mathrm{c}, \mathrm{d}}$ & $156.11 \pm 16.18^{\mathrm{b}}$ \\
\hline
\end{tabular}

Data are shown as means \pm SD of triplicate experiments. Means of individual trials within a column with the different letters are significantly different $(p<0.05)$ with an individual column.

\subsection{Antimicrobial Activity against Pathogenic Bacteria}

The antimicrobial activity of E. faecium OV3-6 was determined as the inhibition zone by the agar well diffusion assay summarized in Table 2. The CFS of E. faecium OV3-6 showed antimicrobial activity against tested strains such as B. cereus ATCC 11778, C. maltaromaticum NCDO 2760, L. innocua CIP $80.11^{\mathrm{T}}$, L. ivanovii SLCC 2379, S. aureus CIP 76.25, and S. mutans ATCC 25175.

Table 2. The antimicrobial activity of CFS produced by E. faecium OV3-6.

\begin{tabular}{|c|c|}
\hline Tested Strains & $\begin{array}{l}\text { Inhibition Zone } \\
(\mathrm{mm})\end{array}$ \\
\hline \multicolumn{2}{|l|}{ Gram-positive bacteria } \\
\hline Bacillus cereus ATCC 11778 & $7.00 \pm 0.10^{\mathrm{d}}$ \\
\hline Brochothrix thermosphacta DSMZ $20171^{\mathrm{T}}$ & NI \\
\hline Carnobacterium maltaromaticum NCDO 2760 & $14.70 \pm 0.24^{\mathrm{b}}$ \\
\hline Clostridium perfringens & NI \\
\hline Listeria innocua CIP $80.11^{\mathrm{T}}$ & $12.05 \pm 0.65^{\mathrm{c}}$ \\
\hline Listeria ivanovii SLCC 2379 & $14.60 \pm 0.30^{b}$ \\
\hline Propionibacterium acnes ATCC 6919 & NI \\
\hline Staphylococcus aureus ATCC 5923 & $\mathrm{NI}$ \\
\hline Staphylococcus aureus CIP 76.25 & $15.63 \pm 0.03^{\mathrm{a}}$ \\
\hline Staphylococcus epidermidis ATCC 12228 & NI \\
\hline Streptococcus mutans ATCC 25175 & $6.25 \pm 0.25^{\mathrm{e}}$ \\
\hline \multicolumn{2}{|l|}{ Gram-negative bacteria } \\
\hline Cronobacter sakazakii ATCC BAA-894 & NI \\
\hline Escherichia coli ATCC 5922 & NI \\
\hline Escherichia coli CIP 76.24 & NI \\
\hline Pseudomonas aeruginosa ATCC 27853 & NI \\
\hline Salmonella Typhi DMST 22842 & NI \\
\hline Salmonella Typhimurium TISTR 1469 & NI \\
\hline Shigella sonnei & NI \\
\hline Vibrio harveyi ATCC BAA-1119 & NI \\
\hline Yeast & \\
\hline Candida albicans ATCC 90028 & NI \\
\hline
\end{tabular}

Data are shown as means \pm SD of triplicate determinations. The different letters indicate that the values are significantly different $(p<0.05)$. The inhibition zone includes diameters of agar well ( $5 \mathrm{~mm}$ of diameter). No inhibition (NI).

The verification of AMPs activity in CFS was assessed by agar well diffusion assay. The neutralized CFS was treated with catalase to remove the hydrogen peroxide effect and proteinase $\mathrm{K}$ to confirm the effect of protein. The result showed the treated CFS had 
antimicrobial activity against S. aureus CIP 76.25 (400 AU/mL). However, the proteinase K causes the CFS to lose the inhibition activity.

\subsection{Confirmation of Bacteriocin-Encoding Gene}

To confirm the presence of the genus Enterococcus spp. gene (ent) and detection of bacteriocin-encoding genes ent $P$, ent50A, ent50B, ent $A s 48$, ent $A$, ent $B$, ent $Q$, and ent 31 in $E$. faecium OV3-6 were evaluated by PCR. Results from agarose gel electrophoresis revealed that $E$. faecium OV3-6 did not harbor any bacteriocin genes except entP, which showed $216 \mathrm{bp}$ of amplification product (Figure 3). The amplification of E. faecium OV3-6 presented of the Enterococcus gene (112 bp) indicated this strain was genus Enterococcus (Figure 3a).

(a)

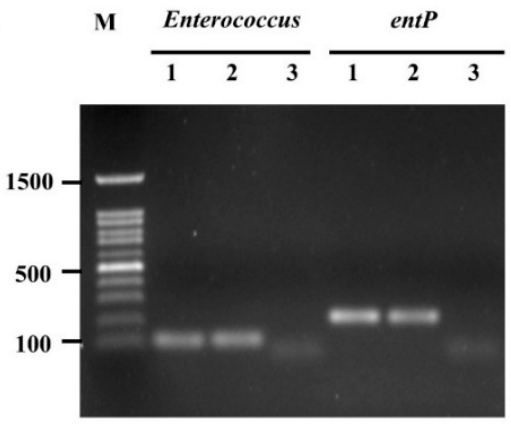

(c)

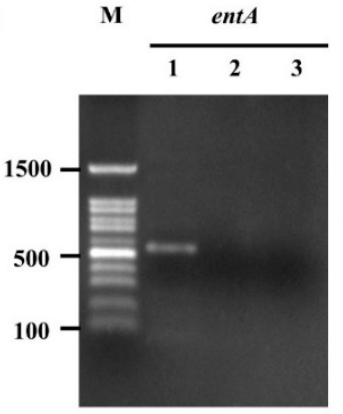

(b)

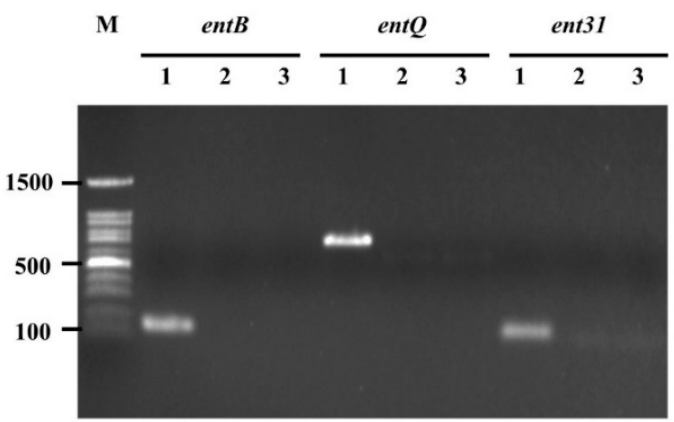

(d)
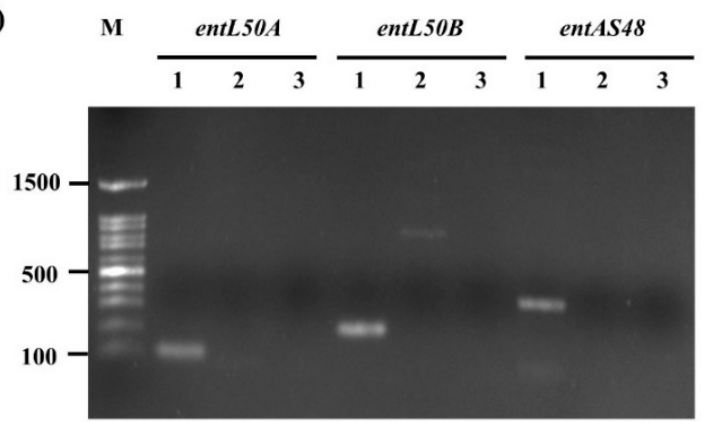

Figure 3. Amplification of genus Enterococcus gene and bacteriocin genes in E. faecium OV3-6 by PCR. (a) Genus Enterococcus and entP genes; (b) entB, ent $Q$, and ent31 genes; (c) ent A gene; (d) entL50A, entL50B, and ent AS48 genes; Lane M: 100 bp DNA markers; Lanes 1: products of positive controls; Lanes 2: products of E. faecium OV3-6; Lanes 3: products of negative controls.

\subsection{Partial Purification of AMPs}

The total protein content in $1000 \mathrm{~mL}$ CFS produced by E. faecium OV3-6 was $1260.00 \mathrm{mg}$ and 400,000 AU of activity. The CFS was purified by two steps, as shown in Table 3 . The first step was $70 \%$ saturation of ammonium sulfate precipitation, which increased the specific activity against strain $S$. aureus CIP 76.25 by 5.57 -folds. The step of the molecular weight cut-off by using Amicon ${ }^{\circledR}$ Ultra centrifugal filter increased the specific activity and the increase in specific activity by $5224.49 \mathrm{AU} / \mathrm{mg}$ and 16.46-folds, respectively.

Table 3. Purification steps of AMPs produced by E. faecium OV3-6.

\begin{tabular}{|c|c|c|c|c|c|c|c|c|}
\hline Step of Purification & $\begin{array}{c}\text { Total } \\
\text { Volume }(\mathrm{mL})\end{array}$ & $\begin{array}{l}\text { Activity } \\
\text { (AU/mL) }\end{array}$ & $\begin{array}{l}\text { Protein } \\
(\mathrm{mg} / \mathrm{mL})\end{array}$ & $\begin{array}{c}\text { Total } \\
\text { Activity } \\
\text { (AU) }\end{array}$ & $\begin{array}{l}\text { Total } \\
\text { Protein } \\
\text { (mg) }\end{array}$ & $\begin{array}{l}\text { Specific } \\
\text { Activity } \\
\text { (AU/mg) }\end{array}$ & $\begin{array}{l}\text { Yield } \\
(\%)\end{array}$ & $\begin{array}{c}\text { Increase in } \\
\text { Specific } \\
\text { Activity (Fold) }\end{array}$ \\
\hline Cell-free supernatant & 1000 & 400 & 1.26 & 400,000 & 1260.00 & 317.46 & 100.00 & 1.00 \\
\hline $\begin{array}{c}\text { Crude }\left(\mathrm{NH}_{4}\right)_{2} \mathrm{SO}_{4} \\
\text { precipitation }\end{array}$ & 100 & 3200 & 1.81 & 320,000 & 181.00 & 1767.96 & 80 & 5.57 \\
\hline Molecular weight cut off & 24 & 12,800 & 2.54 & 307,200 & 58.80 & 5224.49 & 76.80 & 16.46 \\
\hline
\end{tabular}




\subsection{Molecular Mass and Amino Acid Sequence Determination of AMPs}

The partially purified AMPs were separated in SDS-PAGE. The result showed a clear single protein band, and molecular weight was identified at approximately 10-16 kDa (Figure 4). After the partially purified AMPs band from SDS-PAGE was overlaid with S. aureus CIP 76.25, the antimicrobial activity against indicator strain has appeared as an inhibition zone.

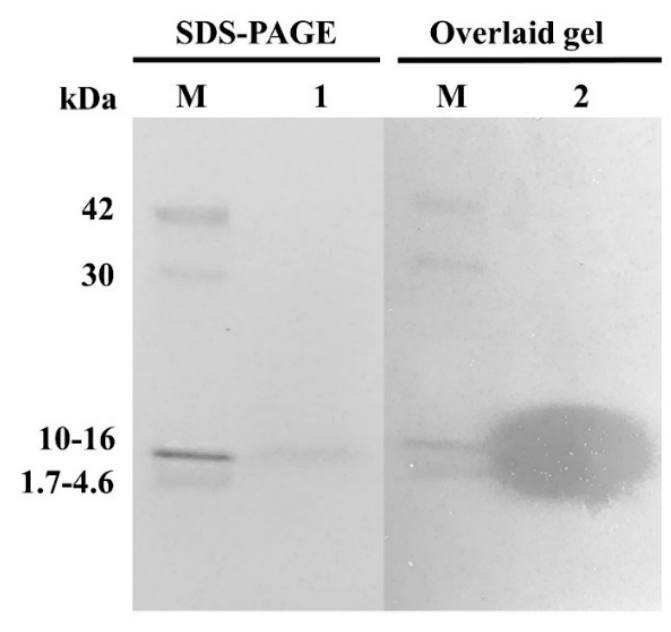

Figure 4. SDS-PAGE of the partially purified AMPs produced by E. faecium OV3-6. Lane M: low molecular weight protein marker (MW 1700-42,000 Da); Lane 1: SDS-PAGE band; Lane 2: inhibition zone of the SDS-PAGE band overlaid with tested strain S. aureus CIP 76.25 in BHI agar.

The amino acid sequence of partially purified AMPs was retrieved from the Mascot Server. The data showed amino acid sequence from 10-16 kDa protein band were matched $(40 \%)$ with 50 S ribosomal proteins L29 of Enterococcus faecalis, which molecular masses of $7.325 \mathrm{kDa}$ and isoelectric point $(\mathrm{pI})$ value of 9.60. This protein matched with the LC-MS/MS spectrum assigned the amino acid sequence ELTTAEMLDKEK and FQLATGQLENTAR (Figure S2).

\subsection{Enzyme Sensitivity, Physicochemical Treatments and Long-Term Storage of AMPS}

The effects of enzymes, temperature $\mathrm{pH}$, and $\mathrm{NaCl}$ on the antimicrobial activity of partially purified AMPs produced by E. faecium OV3-6 (PPA OV3-6) and $1 \mathrm{mg} / \mathrm{mL}$ nisin are shown in Table S2. PPA OV3-6 and nisin were resistant to catalase but completely inactivated by the proteinase enzyme ( $\alpha$-chymotrypsin, trypsin, and proteinase $\mathrm{K})$. After treatment with various temperatures, PPA OV3-6 was heat-stable at temperatures 4, 37, $45,60{ }^{\circ} \mathrm{C}$ for $120 \mathrm{~min}$ and $100{ }^{\circ} \mathrm{C}$ for $15 \mathrm{~min}$. The activity of PPA OV3- 6 and nisin were gradually decreased after heating at $100{ }^{\circ} \mathrm{C}$ for $30-120 \mathrm{~min}$. At autoclave condition, the activity was decreased $25 \%$ from the beginning, but nisin completely disappeared. PPA OV3-6 was found fully active after treatment with $\mathrm{pH} 2-10$, but at $\mathrm{pH} 12$, the activity was lost $50 \%$. In the case of nisin, the activity was stable at $\mathrm{pH} 2-7$ but decreased after treatment with $\mathrm{pH} 8-12$. The $10-30 \%(w / v)$ of $\mathrm{NaCl}$ did not affect both tested substances. In long-term storage, the antimicrobial activity of PPA OV3-6 remained full activity at -20 and $4{ }^{\circ} \mathrm{C}$ till 3 months and at room temperature (RT) after a week of storage. However, $1 \mathrm{mg} / \mathrm{mL}$ nisin at $4{ }^{\circ} \mathrm{C}$ was decreased after three weeks and at RT after a week. At $37^{\circ} \mathrm{C}$ of storage, both tested substances lost $50 \%$ of activity within one week and still gradually decreased until the end of three months of storage.

\section{Discussion}

Enterococcus genus has been an object of increasing scientific work because of its wide range of health-promoting effects for a probiotic [26]. Probiotic E. faecium OV3-6 exhibited survival abilities in simulated gastric juice for $4 \mathrm{~h}(88.16 \%)$. Similar to the observations 
of genus Enterococcus isolated from food sources, Maia reported that E. faecium showed percentage survival between $86-107 \%$ in $\mathrm{pH} 3$ for $4 \mathrm{~h}$ [37]. The proton pumps such as the $F_{1} F_{0}$-ATPase [38] or utilized by the glutamate decarboxylase (GAD) system [39] are important mechanisms involved in the acid resistance regulation of LAB under acidic conditions. Another mechanism is alkali production by the arginine deaminase (ADI) or urease system that increases the cell's internal pH [40]. The OV3-6 also showed high survival (94.33\%) in $0.3 \%$ bile salts and $1 \mathrm{mg} / \mathrm{mL}$ pancreatin for $6 \mathrm{~h}$ of exposure (Figure $\mathrm{S} 1 \mathrm{~b}$ ). The selected E. faecium strains were more resistant to bile salt solution [41,42]. The resistance to bile salt of some LAB strains was also related to BSH enzyme activity, which can hydrolyze combined bile salt and thus reduce their toxic and side effects [43]. This study suggested that E. faecium OV3-6 was more tolerant to the damaging effect of GI tract. Furthermore, the OV3-6 presents positive BSH activity. Our results are consistent with a report by Zhang et al. that found that E. faecium WEFA23, WEFA24, and WEFA30 were efficient in hydrolyzing taurodeoxycholic acid and precipitated out deoxycholate on medium [42]. Normally, the conjugated bile acids were hydrolyzed by the BSH enzyme to unconjugated bile acids. The unconjugated products are precipitated at the low $\mathrm{pH}$ caused by fermentation by LAB. BSH increases the survival and persistence of producing strains in intestinal transit [44].

The hemolytic activity of E. faecium OV3-6 was evaluated to consider a safety prerequisite for selecting a probiotic strain. The strain displayed $\alpha$-hemolysis, indicating that this strain was no hydrolysis of a red blood cell. This result is consistent with the study of Vandera and İspirli [45,46]. However, some strains of Enterococcus spp. isolated from equipment surfaces, raw materials, and traditional cheeses express $\gamma$-hemolysis and $\beta$-hemolysis [47].

Antibiotic resistance in enterococci is a major public health concern. Because these organisms are microbial flora in the GI tract of humans and warm-blooded animals [48], antibiotic-resistant genes might be transferred to opportunistic bacteria during passage in the GI tract via chromosomes, plasmid, or transposons [21]. The E. faecium OV3-6 was sensitive to most clinically relevant antibiotics but only had intermediate sensitivity to erythromycin and kanamycin. This finding is consistent with the previous reports $[49,50]$. They suggest that $E$. faecium is expressed moderately susceptible to erythromycin and kanamycin. Intermediate sensitivity indicates that the microbial strain is under the resistant category. E. faecium can be considered a very poor donor in terms of the erythromycin or kanamycin resistance genes transfer to other enterococci [51]. Applying this strain in vivo by administering may be sensible at the highest possible dose of the antibiotic. However, the candidate probiotic must be more characterized to ensure the absence of antibiotic resistance gene in the genome level in further study.

Enterococci can express genes encoding some virulence factors that may enhance their pathogenicity. Therefore, the virulence factors of E. faecium OV3-6 were investigated to confirm the safety of probiotics. The result shows the only efa $A_{f m}$ (cell wall adhesion in E. faecium) was detected. Our findings are consistent with some reports that $e f a A_{f m}$ gene was present in E. faecium BP8 and E. faecium EYT17 [46,52]. Abouelnaga et al. suggested that the $e f a A_{f m}$ gene was found in various enterococci species isolated from both fermented and unfermented foods. It is possible to explain the distribution of the $e f a A_{f m}$ gene given the nature of its association with E. faecium [53]. However, the efa $A_{f m}$ gene may play a beneficial role for probiotic bacteria. They are presumed to be involved in mechanisms by which the enterococcal cells adhere to biotic and abiotic surfaces [54].

Adherence to the host intestinal surface is considered a principal criterion to exhibit probiotic functional properties. In our study, the capacity of E. faecium OV3-6 showed $89.67 \%$ adhesion rate to the Caco-2 cell, which is a strong adherence range greater than previously published studies [49,55]. This result is not surprising about adherence capable of Enterococcus to gut epithelial cells because they are a common part of the indigenous human microbiota, especially in the GI tract [6]. 
Adhesion is the main mechanism of pathogenic bacteria causing infections in humans and animals. The bacteria involved in severe gastric infections are H. pylori, C. difficile, E. coli, L. monocytogenes, and Salmonella [8]. The living cell of E. faecium OV3-6 reduced the adhesion of E. coli and S. Typhi to Caco-2 cells greater than CFS (Figure 2). One possible explanation for adhesion inhibition in this study is the different proteins located on the bacterial cell wall, which are specific to a receptor on the intestinal epithelial cell of the host [56]. Also, the auto-aggregation and co-aggregation of cells are related to the competition between probiotics and pathogens for adhesion on host tissue $[57,58]$. The secretion of organic acid of probiotics such as lactic and acetic acids related to the intracellular $\mathrm{pH}$ lowering or their intracellular accumulation can cause pathogens' death. In addition, probiotics have been reported to produce bacteriocins that displayed an inhibitory against pathogen bacteria [59].

Immunomodulatory properties play an important role in the mode of action of probiotics. LPS is the major initiator of intestinal epithelial cell (IEC) inflammation and potent immunomodulatory components derived from the cell wall of Gram-negative bacteria such as E. coli and Salmonella $[60,61]$. The immune recognition of LPS is mediated through the toll-like receptor-4 (TLR4) receptor complex in epithelial cells of the intestine and immune cell types, predominantly macrophages, B cells, and dendritic cells [62]. Activation of innate immune cells by LPS via TLR4 initiates the secretion of pro-inflammatory cytokines such as TNF- $\alpha$, IL-1 $\beta$, IL-6, IL-12, and IFN- $\gamma$ [63]. IL-10 is potent immunoregulatory cytokine and anti-inflammatory properties produced by activated macrophages and T cells. IL-10 suppresses $\mathrm{T}$ cell proliferation and the release and function of many pro-inflammatory cytokines, such as IL-1 and IL-6. Probiotic bacteria may regulate the expression of this cytokine [64]. This study showed that E. faecium OV3-6 suppressed the production of pro-inflammatory cytokines IL-6, IL-12 comparing with pathogens and LPS alone. The OV3-6 also augmented the production of anti-inflammatory cytokines IL-10, contributing to intestinal innate immunity and homeostasis regulation. Our results agree with studies of other authors in the macrophage cell line [65] and human enterocyte-like HT-29 cells model [66]. In contrast with E. faecium FC-K, it could induce secretion of pro-inflammatory cytokine TNF- $\alpha$, IL-6, and IL-12 from mouse peritoneal macrophage [67].

CFS's antimicrobial activities produced by E. faecium OV3-6 were active in a narrow spectrum against Gram-positive bacteria but not against Gram-negative bacteria and yeast (Table 2). The various antimicrobial substances secreted in CFS of LAB include organic acids (such as lactic acid, acetic acid, and propionic acid) [68,69], hydrogen peroxide, bacteriocins [59], and other compounds such as some RPs [15,70]. Most of the bacteriocin show inhibit the growth of closely related species [71]. According to the result of this study that $E$. faecium OV3-6 shows antimicrobial activity against only Gram-positive bacteria. In contrast with the report of Vasilchenko et al. that bacteriocin, namely Enterocin-7, showed a broad spectrum against both Gram-positive and Gram-negative bacteria [72]. This study suggests that some antimicrobial substances secreted by E. faecium OV3-6 are proteinaceous compounds as AMPs because activity was not changed after $\mathrm{pH}$ neutralization and treatment with catalase enzyme and after treatment with a proteolytic enzyme, the antimicrobial activity disappeared.

Interestingly, one of the most identified AMPs produced by LAB is bacteriocins. In the present study, E. faecium OV3-6 has been shown carrying out only the entP gene (Figure 3). The bacteriocin-encoding genes entP have been found in Enterococci bacteria, especially in E. faecium [73,74]. The entP encodes a 71-amino-acid prepeptide consisting of a 44 aminoacid mature bacteriocin and a 27-amino-acid signal peptide [75]. Enterocin $\mathrm{P}$ is a class IIa bacteriocins with a very strong anti-listerial effect and a wide range of spoilage and foodborne Gram-positive pathogenic bacteria. Nevertheless, bacteriocin structural gene presence does not necessarily imply the capacity to produce it [76]. It is important to purify and characterize these bacteriocins from E. faecium OV3-6.

The characterization of the active proteinaceous compounds of E. faecium OV3-6 after partial purification and identification by a proteomic analysis base on SDS-PAGE, we found 
only one significant protein band belongs to a mass $10-16 \mathrm{kDa}$ (Figure 4 ). Amino acid sequence from mass spectrometry (LC-MS/MS) analysis has allowed us to identify the active proteinaceous compounds of E. faecium OV3-6 reveals the 50 S ribosomal proteins L29. The antimicrobial activity of the $50 S$ ribosomal proteins $\mathrm{L} 29$ from E. faecium is unprecedented. Ribosomal protein L29 is a component of a large 50S subunit that also possesses antimicrobial activity [14]. This result is in agreement with a few reported secreted RPs identified in other bacteria species. In particular, 30S ribosomal proteins S19, S20, and S21; 50S ribosomal proteins L24 and L29 have been shown in the CFS of Lactobacillus sakei subsp. Sakei 2 a were active against the Listeria spp., Enterococcus spp., S. epidermidis, and $L$. sakei strains [70,77]. Also, 50S ribosomal proteins L29 of Paenibacillus polymyxa Kp10 were antimicrobial proteins against L. monocytogenes [78]. The antimicrobial mechanisms of RPs have been described by Carvalho that secreted RPs of L. sakei subsp. sakei 2a decreased the membrane potential $(\Delta \Psi)$ and increased the ATP efflux in L. monocytogenes [77]. The decrease in $\Delta \Psi$ could be involved several degrees of membrane disruption. The modification of $\Delta \Psi$ has been described already with other AMPs class IIa bacteriocins like enterocin $\mathrm{P}$ [79]. The high isoelectric point of RPs may indicate a high affinity to a negatively charged phosphate group of nucleic acids and bacteria cell membrane. However, this remains to be elucidated [78]. Generally, AMPs are amphiphilic and cationic which means the net charge at neutral $\mathrm{pH}$ varies from +2 to +9 . The polycationic peptides could also attract toward the anionic cell membrane of targeted bacteria via electrostatic interaction. There caused structural microbial membrane disruptions, leading to cell lysis and death [80,81].

50 S ribosomal proteins L29 are mainly active AMPs of our E. faecium OV3-6. Interestingly, these partials purify AMPs also maintain their antimicrobial activity at a wide range of $\mathrm{pH}$ between 2 to 10 . And after various temperature treatments ( 4 to $100{ }^{\circ} \mathrm{C}$ ) for $15 \mathrm{~min}$, their activity did not change, and the activity still appears under autoclaving. The AMPs from OV3-6 were heat-stable. At storage conditions for 12 weeks, we found partial purified AMPs retains its activity at deep freezer and refrigerator condition. A similar study has reported 50S ribosomal proteins L27 and L30 from P. polymyxa Kp10 [15]. The properties of 50 S ribosomal proteins L29 secreted by E. faecium OV3-6 look like the characterized bacteriocin of other Enterococcus under the effect of the enzyme, physicochemical treatments, and stability conditions which showed in many reports. Bacteriocin produced by $E$. faecalis KT11 against some pathogenic bacteria remained stable at $\mathrm{pH}$ values ranging from 2 to 11 and after autoclaving at $121^{\circ} \mathrm{C}$ for $30 \mathrm{~min}$ [82]. The antimicrobial activity of two bacteriocins (bacALP7 and bacALP57) from E. faecium was stable over a wide range of $\mathrm{pH}$ and temperatures [36]. The AMPs produced by E. faecium OV3-6 are suitable to be applied as a bio-preservative agent in functional foods and beverages. Although, nisin is currently the only bacteriocin widely used as a food preservative approved by US-FDA [12]. This study indicates that AMPs of E. faecium OV3-6 are more resistant to a wide range of $\mathrm{pH}$ than nisin, especially in the alkaline range ( $\mathrm{pH} 8-12)$. In addition, it is also more heat-stable under autoclave conditions than nisin. These AMPs may be an alternative natural preservative from probiotics, which have qualifications equivalent to or more than nisin. In further steps, the AMPs will be studied about the mode of action to understand deeply in the animal model. This will make it easy and suitable to be applied as a biopreservative in food.

\section{Conclusions}

Overall, this study demonstrated that E. faecium OV3-6 isolated from fermented (Houttuynia cordata Thunb.) beverage has promising probiotic potential. The outcomes of this work claim that our strain is resistant to simulated GI conditions. The safety assessment revealed that this strain was susceptible to most clinically relevant antibiotics, especially vancomycin, and does not harbor the virulence genes for ace, asal, cylA, cylB, efa $A_{f s}, e s p$, hyl, and gelE. This strain also presents high adhesion capacity and anti-pathogenic bacterial adhesion on the Caco- 2 cell. Additionally, it shows immune-modulatory activity, reducing pro-inflammatory cytokines IL-6 and IL-12 secretion in the Caco-2 cell and inducing the secretion of anti-inflammatory cytokines IL-10. This study is the first report showing $50 \mathrm{~S}$ 
ribosomal proteins $\mathrm{L} 29$ secreted from E. faecium OV3-6 having bactericidal activity. The active protein exhibits heat-stable and stability over a wide $\mathrm{pH}$ range. It may be considered as an interesting candidate for future use as a probiotic and bioprotective for application in the food or feed industries. However, in vivo on animal models and clinical trials are essential to authenticate the safety of E. faecium OV3-6 before it can be incorporated into the human food chain.

Supplementary Materials: The following are available online at https:/ /www.mdpi.com/article/10 .3390 /foods10102264/s1, Table S1: Primers used for PCR amplification of virulence and bacteriocin genes in Enterococcus, Table S2: Enzyme sensitivity, physicochemical treatments, and long-term storage condition on partially purified antimicrobial peptides produced by E. faecium OV3-6 (PPA OV3-6) and $1 \mathrm{mg} / \mathrm{mL}$ commercial preservative nisin, Figure S1: The percentage survival of E. faecium OV3-6 in simulated gastric juice (a) and simulated small intestinal condition (b). Data represent means from three repeats $( \pm \mathrm{SD})$. The different letters above columns indicate that the values are significantly different $(p<0.05)$, Figure S2: Mass spectrometry spectrum of amino acid sequence ELTTAEMLDKEK and F QLATGQLENTAR from 10-16 kDa protein band of E. faecium OV3-6, which matches $50 \mathrm{~S}$ ribosomal proteins $\mathrm{L} 29$ are shown in bold text.

Author Contributions: Conceptualization C.C. and S.S.; methodology, C.C., T.C. and S.S.; validation, C.C. and S.S.; formal analysis, T.C. and S.S.; investigation, T.C., C.C. and S.S.; resources, S.P.; data curation, T.C. and S.S.; writing-original draft preparation, T.C. and S.S.; writing-review and editing, C.C., S.S., K.P., T.C., S.P. and R.W.-S.; visualization, S.S.; supervision, S.S. and C.C.; project administration, S.P.; funding acquisition, S.P. and C.C. All authors have read and agreed to the published version of the manuscript.

Funding: This research was funded by the Research and Researchers for Industry Program (RRI) under the Thailand Research Fund (TRF), grant number PHD56I0037.

Institutional Review Board Statement: Not applicable.

Informed Consent Statement: Not applicable.

Data Availability Statement: The data are available as the Supplementary Documents.

Acknowledgments: This study was partially supported by Chiang Mai University, Chiangmai, Thailand. This study was partially supported by the Graduate School, Chiang Mai University, Thailand. The authors also acknowledge the Faculty of Pharmacy, Chiang Mai University, Thailand, Unit of Excellence (FF64-UoE019), University of Phayao, Thailand for kind assistance in allowing us to conduct the research work. The authors also would like to thank Noraphat Hwanhlem (Faculty of Agriculture, Natural Resources and Environment, Naresuan University, Thailand), Institute National de la Recherche Agronomique (INRA), Nantes, France and Ecole Nationale Nantes Atlantique Vétérinaire, Agroalimentaire et de l'Alimentation (ONIRIS), Nantes, France for donations some bacteria strains used in these experiments.

Conflicts of Interest: The authors have declared no conflict of interest.

\section{References}

1. Sivamaruthi, B.S.; Kesika, P.; Chaiyasut, C. Toxins in fermented foods: Prevalence and preventions-A mini review. Toxins 2019, 11, 4. [CrossRef]

2. García, C.; Rendueles, M.; Díaz, M. Liquid-phase food fermentations with microbial consortia involving lactic acid bacteria: A review. Food Res. Int. 2019, 119, 207-220. [CrossRef]

3. Patel, A.; Prajapati, J.; Holst, O.; Ljungh, A. Determining probiotic potential of exopolysaccharide producing lactic acid bacteria isolated from vegetables and traditional Indian fermented food products. Food Biosci. 2014, 5, 27-33. [CrossRef]

4. FAO (Food and Agriculture Organization); WHO (World Health Organization). Health and Nutritional Properties of Probiotics in Food including Powder Milk with Live Lactic Acid Bacteria: Report of a Joint FAO/WHO Expert Consultation on Evaluation of Health and Nutritional Properties of Probiotics in Food Including Powder Milk with Live Lactic Acid Bacteria; Food and Agriculture Organization; World Health Organization: Córdoba, Argentina, 2001.

5. Le, B.; Yang, S.H. Efficacy of Lactobacillus plantarum in prevention of inflammatory bowel disease. Toxicol. Rep. 2018, 5, $314-317$. [CrossRef] 
6. Ness, I.F.; Diep, D.B.; Ike, Y. Enterococcal bacteriocins and antimicrobial proteins that contribute to niche control. In Enterococci: From Commensals to Leading Causes of Drug Resistant Infection, 1st ed.; Gilmore, M.S., Clewell, D.B., Ike, Y., Shankar, N., Eds.; Massachusetts Eye and Ear Infirmary: Boston, MA, USA, 2014; pp. 466-488.

7. Gao, W.; Howden, B.P.; Stinear, T.P. Evolution of virulence in Enterococcus faecium, a hospital-adapted opportunistic pathogen. Curr. Opin. Microbiol. 2018, 41, 76-82. [CrossRef] [PubMed]

8. Hanchi, H.; Mottawea, W.; Sebei, K.; Hammami, R. The genus Enterococcus: Between probiotic potential and safety concerns-An update. Front. Microbiol. 2018, 9, 1791. [CrossRef] [PubMed]

9. Davoodvandi, A.; Marzban, H.; Goleij, P.; Sahebkar, A.; Morshedi, K.; Rezaei, S.; Mahjoubin-Tehran, M.; Tarrahimofrad, H.; Hamblin, M.R.; Mirzaei, H. Effects of therapeutic probiotics on modulation of microRNAs. Cell Commun. Signal. 2021, 19, 1-22. [CrossRef] [PubMed]

10. Zhang, F.; Qiu, L.; Xu, X.; Liu, Z.; Zhan, H.; Tao, X.; Shah, N.P.; Wei, H. Beneficial effects of probiotic cholesterol-lowering strain of Enterococcus faecium WEFA23 from infants on diet-induced metabolic syndrome in rats. J. Dairy Sci. 2017, 100, 1618-1628. [CrossRef] [PubMed]

11. Ahmadova, A.; Todorov, S.D.; Choiset, Y.; Rabesona, H.; Zadi, T.M.; Kuliyev, A.; de Melo Franco, B.D.G.; Chobert, J.-M.; Haertlé, T. Evaluation of antimicrobial activity, probiotic properties and safety of wild strain Enterococcus faecium AQ71 isolated from Azerbaijani Motal cheese. Food Control 2013, 30, 631-641. [CrossRef]

12. Santos, J.C.; Sousa, R.C.; Otoni, C.G.; Moraes, A.R.; Souza, V.G.; Medeiros, E.A.; Espitia, P.J.; Pires, A.C.; Coimbra, J.S.; Soares, N.F Nisin and other antimicrobial peptides: Production, mechanisms of action, and application in active food packaging. Innov. Food Sci. Emerg. Technol. 2018, 48, 179-194. [CrossRef]

13. Cleveland, J.; Montville, T.J.; Nes, I.F.; Chikindas, M.L. Bacteriocins: Safe, natural antimicrobials for food preservation. Int. J. Food Microbiol. 2001, 71, 1-20. [CrossRef]

14. Ma, Z.; Qu, B.; Yao, L.; Gao, Z.; Zhang, S. Identification and functional characterization of ribosomal protein S23 as a new member of antimicrobial protein. Dev. Comp. Immunol. 2020, 103730. [CrossRef]

15. Pidutti, P.; Federici, F.; Brandi, J.; Manna, L.; Rizzi, E.; Marini, U.; Cecconi, D. Purification and characterization of ribosomal proteins L27 and L30 having antimicrobial activity produced by the Lactobacillus salivarius SGL 03. J. Appl. Microbiol. 2018, 124, 398-407. [CrossRef] [PubMed]

16. Choeisoongnern, T.; Sivamaruthi, B.S.; Sirilun, S.; Peerajan, S.; Choiset, Y.; Rabesona, H.; Haertlé, T.; Chaiyasut, C. Screening and identification of bacteriocin-like inhibitory substances producing lactic acid bacteria from fermented products. Food Sci. Technol. 2019, 40, 571-579. [CrossRef]

17. Hwanhlem, N.; Ivanova, T.; Biscola, V.; Choiset, Y.; Haertlé, T. Bacteriocin producing Enterococcus faecalis isolated from chicken gastrointestinal tract originating from Phitsanulok, Thailand: Isolation, screening, safety evaluation and probiotic properties. Food Control 2017, 78, 187-195. [CrossRef]

18. Oh, A.; Daliri, E.B.-M.; Oh, D.H. Screening for potential probiotic bacteria from Korean fermented soybean paste: In Vitro and Caenorhabditis elegans model testing. LWT 2018, 88, 132-138. [CrossRef]

19. Shehata, M.; El Sohaimy, S.; El-Sahn, M.A.; Youssef, M. Screening of isolated potential probiotic lactic acid bacteria for cholesterol lowering property and bile salt hydrolase activity. Ann. Agric. Sci. 2016, 61, 65-75. [CrossRef]

20. Al Atya, A.K.; Drider-Hadiouche, K.; Ravallec, R.; Silvain, A.; Vachee, A.; Drider, D. Probiotic potential of Enterococcus faecalis strains isolated from meconium. Front. Microbiol. 2015, 6, 227. [CrossRef]

21. Nueno-Palop, C.; Narbad, A. Probiotic assessment of Enterococcus faecalis CP58 isolated from human gut. Int. J. Food Microbiol. 2011, 145, 390-394. [CrossRef]

22. Hwanhlem, N.; Biscola, V.; El-Ghaish, S.; Jaffrès, E.; Dousset, X.; Haertlé, T.; Aran, H.; Chobert, J.-M. Bacteriocin-producing lactic acid bacteria isolated from mangrove forests in Southern Thailand as potential bio-control agents: Purification and characterization of bacteriocin produced by Lactococcus lactis subsp. lactis KT2W2L. Probiotics Antimicrob. Proteins 2013, 5, 264-278. [CrossRef]

23. Vankerckhoven, V.; Van Autgaerden, T.; Vael, C.; Lammens, C.; Chapelle, S.; Rossi, R.; Jabes, D.; Goossens, H. Development of a multiplex PCR for the detection of asa1, gelE, cylA, esp, and hyl genes in enterococci and survey for virulence determinants among European hospital isolates of Enterococcus faecium. J. Clin. Microbiol. 2004, 42, 4473-4479. [CrossRef] [PubMed]

24. Moroni, O.; Kheadr, E.; Boutin, Y.; Lacroix, C.; Fliss, I. Inactivation of adhesion and invasion of food-borne Listeria monocytogenes by bacteriocin-producing Bifidobacterium strains of human origin. Appl. Environ. Microbiol. 2006, 72, 6894-6901. [CrossRef]

25. Vimont, A.; Fernandez, B.; Hammami, R.; Ababsa, A.; Daba, H.; Fliss, I. Bacteriocin-producing Enterococcus faecium LCW 44 : A high potential probiotic candidate from raw camel milk. Front. Microbiol. 2017, 8, 865. [CrossRef]

26. Bengoa, A.A.; Zavala, L.; Carasi, P.; Trejo, S.A.; Bronsoms, S.; de los Ángeles Serradell, M.; Garrote, G.L.; Abraham, A.G. Simulated gastrointestinal conditions increase adhesion ability of Lactobacillus paracasei strains isolated from kefir to Caco-2 cells and mucin. Food Res. Int. 2018, 103, 462-467. [CrossRef] [PubMed]

27. Koryszewska-Bagińska, A.; Gawor, J.; Nowak, A.; Grynberg, M.; Aleksandrzak-Piekarczyk, T. Comparative genomics and functional analysis of a highly adhesive dairy Lactobacillus paracasei subsp. paracasei IBB3423 strain. Appl. Microbiol. Biotechnol. 2019, 103, 7617-7634. [CrossRef] [PubMed] 
28. Aspri, M.; O'Connor, P.M.; Field, D.; Cotter, P.D.; Ross, P.; Hill, C.; Papademas, P. Application of bacteriocin-producing Enterococcus faecium isolated from donkey milk, in the bio-control of Listeria monocytogenes in fresh whey cheese. Int. Dairy J. 2017, 73, 1-9. [CrossRef]

29. Xi, Q.; Wang, J.; Du, R.; Zhao, F.; Han, Y.; Zhou, Z. Purification and Characterization of Bacteriocin Produced by a Strain of Enterococcus faecalis TG2. Appl. Biochem. Biotechnol. 2018, 184, 1106-1119. [CrossRef]

30. Ke, D.; Picard, F.J.; Martineau, F.; Ménard, C.; Roy, P.H.; Ouellette, M.; Bergeron, M.G. Development of a PCR assay for rapid detection of enterococci. J. Clin. Microbiol. 1999, 37, 3497-3503. [CrossRef]

31. Aran, H.; Biscola, V.; El-Ghaish, S.; Jaffres, E.; Dousset, X.; Pillot, G.; Haertle, T.; Chobert, J.-M.; Hwanhlem, N. Bacteriocinproducing Enterococcus faecalis KT2W2G isolated from mangrove forests in southern Thailand: Purification, characterization and safety evaluation. Food Control 2015, 54, 126-134.

32. Goh, H.F.; Philip, K. Isolation and mode of action of bacteriocin BacC1 produced by nonpathogenic Enterococcus faecium C1. J. Dairy Sci. 2015, 98, 5080-5090. [CrossRef]

33. Laemmli, U.K. Cleavage of structural proteins during the assembly of the head of bacteriophage T4. Nature 1970, 227, 680-685 [CrossRef]

34. Bringans, S.; Eriksen, S.; Kendrick, T.; Gopalakrishnakone, P.; Livk, A.; Lock, R.; Lipscombe, R. Proteomic analysis of the venom of Heterometrus longimanus (Asian black scorpion). Proteomics 2008, 8, 1081-1096. [CrossRef]

35. Wannun, P.; Piwat, S.; Teanpaisan, R. Purification and characterization of bacteriocin produced by oral Lactobacillus paracasei SD1. Anaerobe 2014, 27, 17-21. [CrossRef]

36. Pinto, A.L.; Fernandes, M.; Pinto, C.; Albano, H.; Castilho, F.; Teixeira, P.; Gibbs, P.A. Characterization of anti-Listeria bacteriocins isolated from shellfish: Potential antimicrobials to control non-fermented seafood. Int. J. Food Microbiol. 2009, 129, 50-58. [CrossRef]

37. Maia, L.F.; Giazzi, A.; Brandalize, C.; Katsuda, M.S.; Rocha, K.; Real, A.; Terra, M.; Regina, A.; Furlaneto, M.; Cristina, A. Isolation and characterization of potential probiotic enterococci strains from soft cheese flora. Afr. J. Microbiol. Res. 2017, 11, 482-487.

38. Papadimitriou, K.; Alegría, Á.; Bron, P.A.; De Angelis, M.; Gobbetti, M.; Kleerebezem, M.; Lemos, J.A.; Linares, D.M.; Ross, P.; Stanton, C. Stress physiology of lactic acid bacteria. Microbiol. Mol. Biol. Rev. 2016, 80, 837-890. [CrossRef]

39. Wang, C.; Cui, Y.; Qu, X. Mechanisms and improvement of acid resistance in lactic acid bacteria. Arch. Microbiol. 2018, 200, 195-201. [CrossRef] [PubMed]

40. Corcoran, B.; Stanton, C.; Fitzgerald, G.; Ross, R. Survival of probiotic lactobacilli in acidic environments is enhanced in the presence of metabolizable sugars. Appl. Environ. Microbiol. 2005, 71, 3060-3067. [CrossRef]

41. Dowdell, P.; Chankhamhaengdecha, S.; Panbangred, W.; Janvilisri, T.; Aroonnual, A. Probiotic activity of Enterococcus faecium and Lactococcus lactis isolated from Thai fermented sausages and their protective effect against Clostridium difficile. Probiotics Antimicrob. Proteins 2020, 12, 641-648. [CrossRef] [PubMed]

42. Zhang, F.; Jiang, M.; Wan, C.; Chen, X.; Chen, X.; Tao, X.; Shah, N.P.; Wei, H. Screening probiotic strains for safety: Evaluation of virulence and antimicrobial susceptibility of enterococci from healthy Chinese infants. J. Dairy Sci. 2016, 99, 4282-4290. [CrossRef]

43. Argyri, A.A.; Zoumpopoulou, G.; Karatzas, K.-A.G.; Tsakalidou, E.; Nychas, G.-J.E.; Panagou, E.Z.; Tassou, C.C. Selection of potential probiotic lactic acid bacteria from fermented olives by in vitro tests. Food Microbiol. 2013, 33, 282-291. [CrossRef]

44. Begley, M.; Hill, C.; Gahan, C.G. Bile salt hydrolase activity in probiotics. Appl. Environ. Microbiol. 2006, 72, 1729-1738. [CrossRef]

45. Vandera, E.; Tsirka, G.; Kakouri, A.; Koukkou, A.-I.; Samelis, J. Approaches for enhancing in situ detection of enterocin genes in thermized milk, and selective isolation of enterocin-producing Enterococcus faecium from Baird-Parker agar. Int. J. Food Microbiol. 2018, 281, 23-31. [CrossRef]

46. İspirli, H.; Demirbaş, F.; Dertli, E. Characterization of functional properties of Enterococcus spp. isolated from Turkish white cheese. LWT 2017, 75, 358-365. [CrossRef]

47. Gaglio, R.; Couto, N.; Marques, C.; Lopes, M.d.F.S.; Moschetti, G.; Pomba, C.; Settanni, L. Evaluation of antimicrobial resistance and virulence of enterococci from equipment surfaces, raw materials, and traditional cheeses. Int. J. Food Microbiol. 2016, 236, 107-114. [CrossRef]

48. Golob, M.; Pate, M.; Kušar, D.; Dermota, U.; Avberšek, J.; Papić, B.; Zdovc, I. Antimicrobial Resistance and virulence genes in Enterococcus faecium and Enterococcus faecalis from humans and retail red meat. Biomed. Res. Int. 2019, 2019, 2815279. [CrossRef]

49. Bagci, U.; Togay, S.O.; Temiz, A.; Ay, M. Probiotic characteristics of bacteriocin-producing Enterococcus faecium strains isolated from human milk and colostrum. Folia Microbiol. 2019, 64, 735-750. [CrossRef]

50. Basanta, A.; Gómez-Sala, B.; Sánchez, J.; Diep, D.B.; Herranz, C.; Hernández, P.E.; Cintas, L.M. Use of the yeast Pichia pastoris as an expression host for secretion of enterocin L50, a leaderless two-peptide (L50A and L50B) bacteriocin from Enterococcus faecium L50. Appl. Environ. Microbiol. 2010, 76, 3314-3324. [CrossRef]

51. Toit, M.D.; Franz, C.; Dicks, L.; Holzapfel, W. Preliminary characterization of bacteriocins produced by Enterococcus faecium and Enterococcus faecalis isolated from pig faeces. J. Appl. Microbiol. 2000, 88, 482-494. [CrossRef]

52. Tuncer, B.Ö.; Ay, Z.; Tuncer, Y. Occurrence of enterocin genes, virulence factors, and antibiotic resistance in 3 bacteriocin-producer Enterococcus faecium strains isolated from Turkish tulum cheese. Turk. J. Biol. 2013, 37, 443-449. [CrossRef]

53. Abouelnaga, M.; Lamas, A.; Quintela-Baluja, M.; Osman, M.; Miranda, J.M.; Cepeda, A.; Franco, C.M. Evaluation of the extent of spreading of virulence factors and antibiotic resistance in Enterococci isolated from fermented and unfermented foods. Ann. Microbiol. 2016, 66, 577-585. [CrossRef] 
54. Mannu, L.; Paba, A.; Daga, E.; Comunian, R.; Zanetti, S.; Duprè, I.; Sechi, L.A. Comparison of the incidence of virulence determinants and antibiotic resistance between Enterococcus faecium strains of dairy, animal and clinical origin. Int. J. Food Microbiol. 2003, 88, 291-304. [CrossRef]

55. Sharma, C.; Gulati, S.; Thakur, N.; Singh, B.P.; Gupta, S.; Kaur, S.; Mishra, S.K.; Puniya, A.K.; Gill, J.P.S.; Panwar, H. Antibiotic sensitivity pattern of indigenous lactobacilli isolated from curd and human milk samples. 3 Biotech 2017, 7, 53. [CrossRef]

56. Mathipa, M.G.; Bhunia, A.K.; Thantsha, M.S. Internalin AB-expressing recombinant Lactobacillus casei protects Caco-2 cells from Listeria monocytogenes-induced damages under simulated intestinal conditions. PLoS ONE 2019, 14, e0220321. [CrossRef]

57. He, Y.; Xu, X.; Zhang, F.; Xu, D.; Liu, Z.; Tao, X.; Wei, H. Anti-adhesion of probiotic Enterococcus faecium WEFA23 against 5 pathogens and the beneficial effect of its S-layer proteins against Listeria monocytogenes. Can. J. Microbiol. 2019, 65, 175-184. [CrossRef]

58. Veljović, K.; Popović, N.; Miljković, M.; Tolinački, M.; Terzić-Vidojević, A.; Kojić, M. Novel aggregation promoting factor AggE contributes to the probiotic properties of Enterococcus faecium BGGO9-28. Front. Microbiol. 2017, 8, 1843. [CrossRef] [PubMed]

59. Reis, J.; Paula, A.; Casarotti, S.; Penna, A. Lactic acid bacteria antimicrobial compounds: Characteristics and applications. Food Eng. Rev. 2012, 4, 124-140. [CrossRef]

60. Kern, M.; Günzel, D.; Aschenbach, J.R.; Tedin, K.; Bondzio, A.; Lodemann, U. Altered cytokine expression and barrier properties after in vitro infection of porcine epithelial cells with enterotoxigenic Escherichia coli and probiotic Enterococcus faecium. Mediat. Inflamm. 2017, 2017. [CrossRef]

61. Yeung, C.Y.; Chiang Chiau, J.S.; Chan, W.T.; Jiang, C.B.; Cheng, M.L.; Liu, H.L.; Lee, H.C. In vitro prevention of Salmonella lipopolysaccharide-induced damages in epithelial barrier function by various Lactobacillus strains. Gastroenterol. Res. Pract. 2013, 2013, 973209. [CrossRef]

62. Rodes, L.; Khan, A.; Paul, A.; Coussa-Charley, M.; Marinescu, D.; Tomaro-Duchesneau, C.; Shao, W.; Kahouli, I.; Prakash, S. Effect of probiotics Lactobacillus and Bifidobacterium on gut-derived lipopolysaccharides and inflammatory cytokines: An in vitro study using a human colonic microbiota model. J. Microbiol. Biotechnol. 2013, 23, 518-526. [CrossRef] [PubMed]

63. Li, C.C.; Munitic, I.; Mittelstadt, P.R.; Castro, E.; Ashwell, J.D. Suppression of dendritic cell-derived IL-12 by endogenous glucocorticoids is protective in LPS-induced sepsis. PLoS Biol. 2015, 13, e1002269. [CrossRef]

64. Chen, C.-Y.; Tsen, H.-Y.; Lin, C.-L.; Yu, B.; Chen, C.-S. Oral administration of a combination of select lactic acid bacteria strains to reduce the Salmonella invasion and inflammation of broiler chicks. Poult. Sci. 2012, 91, 2139-2147. [CrossRef]

65. Li, W.; Huang, Q.; Li, Y.; Rajput, I.R.; Huang, Y.; Hu, C. Induction of probiotic strain Enterococcus faecium EF1 on the production of cytokines, superoxide anion and prostaglandin E2 in a macrophage cell line. Pak. Vet. J. 2012, 32, 530-534.

66. Tian, Z.; Yang, L.; Li, P.; Xiao, Y.; Peng, J.; Wang, X.; Li, Z.; Liu, M.; Bi, D.; Shi, D. The inflammation regulation effects of Enterococcus faecium HDRsEf1 on human enterocyte-like HT-29 cells. Anim. Cells Syst. 2016, 20, 70-76. [CrossRef]

67. Rho, M.K.; Kim, Y.E.; Rho, H.I.; Kim, T.R.; Kim, Y.B.; Sung, W.K.; Kim, T.W.; Kim, D.O.; Kang, H. FC-K Derived from Kimchi Is a Probiotic Strain That Shows Anti-Allergic Activity. J. Microbiol. Biotechnol. 2017, 27, 1071-1077. [CrossRef] [PubMed]

68. Hussain, N.; Tariq, M.; Saris, P.E.J.; Zaidi, A. Evaluation of the probiotic and postbiotic potential of lactic acid bacteria from artisanal dairy products against pathogens. J. Infect. Dev. Ctries. 2021, 15, 102-112. [CrossRef] [PubMed]

69. Waheed, S.; Rasool, M.H.; ASLAM, B.; Muzammil, S.; WASEEM, M.; Shahid, M.; Saqib, M.; Hayat, S.; Naeem, M.; Taj, Z. Antagonistic Potential of Dairy Origin Enterococcus faecium Against Multidrug-Resistant Foodborne Pathogens. Rom. Biotechnol. Lett. 2021, 26, 2406-2415. [CrossRef]

70. De Carvalho, K.G.; Bambirra, F.H.; Kruger, M.F.; Barbosa, M.S.; Oliveira, J.S.; Santos, A.M.; Nicoli, J.R.; Bemquerer, M.P.; de Miranda, A.; Salvucci, E.J. Antimicrobial compounds produced by Lactobacillus sakei subsp. sakei 2a, a bacteriocinogenic strain isolated from a Brazilian meat product. J. Ind. Microbiol. Biotechnol. 2010, 37, 381-390. [CrossRef]

71. Favaro, L.; Basaglia, M.; Casella, S.; Hue, I.; Dousset, X.; de Melo Franco, B.D.G.; Todorov, S.D. Bacteriocinogenic potential and safety evaluation of non-starter Enterococcus faecium strains isolated from home made white brine cheese. Food Microbiol. 2014, 38, 228-239. [CrossRef] [PubMed]

72. Vasilchenko, A.; Vasilchenko, A.; Valyshev, A.; Rogozhin, E. A novel high-molecular-mass bacteriocin produced by Enterococcus faecium: Biochemical features and mode of action. Probiotics Antimicrob. Proteins 2018, 10, 427-434. [CrossRef] [PubMed]

73. Brandão, A.; Almeida, T.; Muñoz-Atienza, E.; Torres, C.; Igrejas, G.; Hernández, P.; Cintas, L.; Poeta, P.; Herranz, C. Antimicrobial activity and occurrence of bacteriocin structural genes in Enterococcus spp. of human and animal origin isolated in Portugal. Arch. Microbiol. 2010, 192, 927-936. [CrossRef] [PubMed]

74. Cintas, L.M.; Casaus, P.; Håvarstein, L.S.; Hernandez, P.E.; Nes, I.F. Biochemical and genetic characterization of enterocin P, a novel sec-dependent bacteriocin from Enterococcus faecium P13 with a broad antimicrobial spectrum. Appl. Environ. Microbiol. 1997, 63, 4321-4330. [CrossRef]

75. Gutiérrez, J.; Criado, R.; Martín, M.; Herranz, C.; Cintas, L.M.; Hernández, P.E. Production of enterocin P, an antilisterial pediocin-like bacteriocin from Enterococcus faecium P13, in Pichia pastoris. Antimicrob. Agents Chemother. 2005, 49, 3004-3008. [CrossRef]

76. Liu, G.; Griffiths, M.W.; Wu, P.; Wang, H.; Zhang, X.; Li, P. Enterococcus faecium LM-2, a multi-bacteriocinogenic strain naturally occurring in "Byaslag", a traditional cheese of Inner Mongolia in China. Food Control 2011, 22, 283-289. [CrossRef] 
77. Carvalho, K.G.; Bambirra, F.H.S.; Nicoli, J.R.; Oliveira, J.S.; Santos, A.M.C.; Bemquerer, M.P.; Miranda, A.; Franco, B.D.G.M. Characterization of multiple antilisterial peptides produced by sakacin P-producing Lactobacillus sakei subsp. sakei 2a. Arch. Microbiol. 2018, 200, 635-644. [CrossRef] [PubMed]

78. Mokhtar, N.F.K.; Hashim, A.M.; Hanish, I.; Zulkarnain, A.; Nhari, R.M.H.R.; Sani, A.A.A.; Abbasiliasi, S.; Ariff, A.; Mustafa, S.; Rahim, R.A. The Discovery of New Antilisterial Proteins From Paenibacillus polymyxa Kp10 via Genome Mining and Mass Spectrometry. Front. Microbiol. 2020, 11, 960. [CrossRef]

79. Herranz, C.; Cintas, L.M.; Hernández, P.E.; Moll, G.N.; Driessen, A.J. Enterocin P causes potassium ion efflux from Enterococcus faecium T136 cells. Antimicrob. Agents Chemother. 2001, 45, 901-904. [CrossRef] [PubMed]

80. Ciumac, D.; Gong, H.; Hu, X.; Lu, J.R. Membrane targeting cationic antimicrobial peptides. J. Colloid Interface Sci. 2019, 537, 163-185. [CrossRef]

81. Hoskin, D.W.; Ramamoorthy, A. Studies on anticancer activities of antimicrobial peptides. Biochim. Biophys. Acta (BBA) Biomembr. 2008, 1778, 357-375. [CrossRef] [PubMed]

82. Abanoz, H.S.; Kunduhoglu, B. Antimicrobial activity of a bacteriocin produced by Enterococcus faecalis KT11 against some pathogens and antibiotic-resistant bacteria. Korean J. Food Sci. Anim. Resour. 2018, 38, 1064. [CrossRef] [PubMed] 